4. Pfreundschuh, M., Trümper, L., Osterborg, A., Pettengell, R., Trneny, M., Imrie, K., Ma, D., Gill, D., Walewski, J., Zinzani, P. L., Stahel, R., Kvaloy, S., Shpilberg, O., Jaeger, U., Hansen, M., Lehtinen, T., LópezGuillermo, A., Corrado, C., Scheliga, A., Milpied, N., ... MabThera International Trial Group (2006). CHOP-like chemotherapy plus rituximab versus $\mathrm{CHOP}$-like chemotherapy alone in young patients with good-prognosis diffuse largeB-cell lymphoma: a randomised controlled trial by the MabThera International Trial (MInT) Group. The Lancet. Oncology, 7(5), 379-391. https://doi.org/10.1016/S1470-2045(06)70664-7

5. Coiffier, B., Thieblemont, C., Van Den Neste, E. Lepeu, G., Plantier, I., Castaigne, S., Lefort, S., Marit, G., Macro, M., Sebban, C., Belhadj, K.,
Bordessoule, D., Fermé, C., \& Tilly, H. (2010) Long-term outcome of patients in the LNH-98.5 trial, the first randomized study comparing rituximab-CHOP to standard CHOP chemotherapy in DLBCL patients: a study by the Groupe d'Etudes des Lymphomes de l'Adulte. Blood, 116(12), 20402045. https://doi.org/10.1182/blood-2010-03276246

6. Trân Xuân Dũng, (2018). Đánh giá kết quả điều tri bênh u lympho ác tính không Hodgkin tế bào $B$ lớn lan tỏa tái phát, Luân văn thạc sĩ y học, Đại hoc Y Hà Nôi.

7. Pham Thi Quế. (2012). Đánh giá kết quả điều trị hóa chất phác đồ r-chop trong u lympho ác tính không hodgkin tế bào $B$ tai bệnh viện $K$, Luận văn thạc sĩ y học, Đại học Y Hà Nội.

\title{
KHẢO SÁT NỒNG ĐỘ 25-(OH)D HUYẾT THANH Ở TRẺ EM VIÊM TIỂU PHẾ QUẢN ĐIỀU TRI TẠI BỆNH VIỆN NHI TRUNG ƯO'NG
}

\section{TÓM TẮT}

Vitamin $D$ đã được chứng minh có vai trò quan trong đối với hệ miễn dịch của cơ thể, bao gôm cả miễn dịch bẩm sinh và miễn dịch thu được. Mục tiêu: Khảo sát nồng đô $25-(\mathrm{OH}) \mathrm{D}$ huyết thanh ở trẻ viêm tiểu phế quản (VTPQ) và nhân xét một số liên quan giữa nồng độ $25-(\mathrm{OH}) \mathrm{D}$ huyết thanh và mức độ nặng của VTPQ. Đối tượng và phương pháp: 108 trẻ VTPQ điều tri tai bênh viện Nhi Trung ương từ tháng 7 năm 2020 đến tháng 6 năm 2021. Đây là nghiên cứu mô tả cắt ngang. Kết quả: VTPQ mức độ nhe chiếm tỷ lệ cao nhất là 62,04\%, mức độ nặng là 15,74\%. Có $14,82 \%$ trẻ VTPQ có nồng đô $25-(\dot{\mathrm{OH}}) \mathrm{D}$ huyết thanh thấp (< $50 \mathrm{nmol} / \mathrm{l})$. Có $21,05 \%$ trẻ VTPQ mức độ nặng ở nhóm có nồng đô $25-(\mathrm{OH}) \mathrm{D}$ dưới $75 \mathrm{nmol} / \mathrm{l}$ so với $12,86 \%$ ở nhóm VTPQ có nồng độ $25-(\mathrm{OH}) \mathrm{D} \geq 75$ $n m o l / l$, với $p=0,022$. Kết luân: Nồng đô̂ $25-(\mathrm{OH}) \mathrm{D}$ huyết thanh có liên quan đến mức độ nặng của bệnh viêm tiểu phế quản ở trẻ em.

Tư khóa: Viêm tiểu phế quản, nông độ 25-(OH)D huyết thanh, mức độ nặng.

\section{SUMMARY \\ THE CONCENTRATION OF SERUM 25(OH)D IN CHILDREN WITH BRONCHIOLITIS TREATED AT THE VIETNAM NATIONAL CHILDREN'S HOSPITAL}

Vitamin $\mathrm{D}$ plays an important role in the immune system, including both innate and adaptive immunity. Objectives: To investigate the concentration of serum

*Trường Đai hoc Y Hà Nôi

Chịu trách nhiệm chính: Phạm Văn Dương

Email: duongpham.6666@gmail.com

Ngày nhận bài: 4.6.2021

Ngày phản biên khoa hoc: 26.7.2021

Ngày duyệt bài: 5.8.2021

\section{Phạm Văn Dương*, Nguyễn Thị Diệu Thúy*}

$25-(\mathrm{OH}) \mathrm{D}$ in children with bronchiolitis and the relationship between the concentration of serum 25$(\mathrm{OH}) \mathrm{D}$ and the severity of bronchiolitis. Subjects and methodS: 108 children with bronchiolitis treated at the Vietnam National Children's Hospital from July 2020 to June 2021. This was a descriptive crosssectional study. Results: Mild bronchiolitis accounted for the highest rate with $62.04 \%$ and severe bronchiolitis was $15.74 \%$. There was $14.82 \%$ children with bronchiolitis had low serum 25-(OH)D concentrations ( $<50 \mathrm{nmol} / \mathrm{l}) .21 .05 \%$ of group having serum $25-(\mathrm{OH}) \mathrm{D}$ concentrations less than $75 \mathrm{nmol} / \mathrm{l}$ suffered from severe bronchiolitis compared with $12.86 \%$ in group of serum $25-(\mathrm{OH}) \mathrm{D}$ concentrations equal or more than $75 \mathrm{nmol} / \mathrm{l}$, with $\mathrm{p}=0.022$. Conclusion: The serum $25-(\mathrm{OH}) \mathrm{D}$ concentration is associated with the severity of bronchiolitis in children.

Keywords: Bronchiolitis, serum 25-(OH)D concentration, severity of disease.

\section{I. ĐĂT VẤN ĐỀ}

Viêm tiểu phế quản (VTPQ) là bệnh nhiễm khuẩn đường hô hấp dưới phổ biến ở trẻ em dưới 2 tuổi. Bệnh có thể diễn biến từ mức độ nhẹ, tự khỏi nhưng cũng có thể nặng dẫn tới tử vong (1).

Vitamin $\mathrm{D}$ là loại vitamin được hấp thu cùng chất béo ở ruột non, có vai trò quan trọng trong sự phát triển của hệ xương và các hệ cớ quan khác. Nhiều nghiên cứu đã chỉ ra tỷ lệ thiếu vitamin D rất cao ở các quốc gia. Ở châu Phi, có tới gần $60 \%$ dân số thiếu vitamin $D$ và $34,22 \%$ dân số thiếu vitamin $D$ nặng (2). Ở Việt Nam, một nghiên cứu năm 2013 chỉ ra có tới $59 \%$ trẻ em thiếu vitamin D (3). Nghiên cứu đa quốc gia tiến hành ở trẻ em 6 tháng tới 12 tuổi cho kết quả tỷ lệ thiếu vitamin $D$ ở trẻ em thành phố và nông 
thôn Việt Nam lần lượt là 52,2\% và 46,1\% (4).

Ngày nay, các nghiên cứu đã chứng minh được vai trò của vitamin $D$ đối với hệ miền dịch của cơ thể. Vitamin $D$ tham gia vào điều hòa miễn dịch tại đường hô hấp, giúp tăng cường miễn dịch nhờ tăng lớp chất nhâyy ở niêm mạc đường hô hấp và giảm phản ứng miễn dịch khi phản ứng xảy ra quá mạnh; thúc đẩy sản xuất peptid LL-37 có tác dụng mạnh, chống lại cả vi khuẩn và virus, bao gồm cả vi khuẩn lao (5). Như vậy, khi thiếu vitamin $D$ sẽ ảnh hưởng tới khả nằng miễn dịch của cơ thể nói chung và miễn dịch đường hô hấp nói riêng. Câu hỏi nghiên cứu đặt ra là liệu có mối liên quan giữa nồng độ vitamin $D$ huyết thanh và mức độ nặng viêm tiểu phế quản ở trẻ em. Để trả lời câu hỏi này, chúng tôi tiến hành khảo sát nồng độ 25$(\mathrm{OH}) \mathrm{D}$ huyết thanh và đánh giá mối liên quan giữa nồng độ $25-(\mathrm{OH}) \mathrm{D}$ huyết thanh với mức độ nặng của VTPQ.

\section{II. ĐỐI TƯỢNG VÀ PHƯƠNG PHÁP NGHIÊN CỨU}

Đối tượng nghiên cứu: Trẻ em được chẩn đoán viêm tiểu phế quản điều trị tại bệnh viện Nhi Trung ương từ tháng 7 năm 2020 đển tháng 6 năm 2021.

Tiêu chuẩn lựa chọn:

$\checkmark$ Trẻ được chẩn đoán xác định viêm tiểu phế quản.

$\checkmark$ Trẻ được làm xét nghiệm 25-(OH)D.

$\checkmark$ Gia đình trẻ đồng ý tham gia nghiên cứu.

Tiêu chuẩn loại trừ:

$\checkmark$ Trẻ viêm tiểu phế quản có bệnh lý nặng kèm theo như bệnh lý đường tiêu hóa (hội chứng ruột viêm, tiêu chảy mạn tính...), suy thận mạn, suy gan, bệnh tim mạch...

Phương pháp nghiên cứu

Thiết kế nghiên cứu: Nghiên cứu mô tả cắt ngang.

Cỡ mẫu và phương pháp chọn mẫu: Chọn mẫu thuận tiện, lấy tất cả bệnh nhân đủ tiều chuẩn được mời tham gia nghiển cứu.

Quy trình nghiên cứu: Các trẻ viêm tiểu phế quản được khai thác thông tin chung, tiền sử, bệnh sử, khám lâm sàng, đánh giá mức độ nặng theo bảng phân loại của New Zealand. Trẻ được lấy máu làm xét nghiệm định lượng nồng độ 25-(OH)D huyết thanh.

Xử lý số liệu: Phân tích và xử lý số liệu theo thuật toán thống kê y học, sử dụng phần mềm Stata 13.0. Sự khác biệt có ý nghĩa thống kê khi $\mathrm{p}<0,05$.

Đạo đức nghiên cứu: Nghiên cứu được sự chấp thuận của Hội đồng đạo đức Trường Đại học Y Hà Nội.

\section{KẾT QUẢ NGHIÊN CỨU}

Trong thời gian nghiên cứu, có 108 trẻ VTPQ đến khám và điều trị tai bênh viên Nhi Trung ương, đủ tiêu chuẩn được lựa chọn được mời tham gia nghiên cứu.

Bảng 1. Đặc điểm chung của đôî tượng nghiên cứu

\begin{tabular}{|c|c|c|c|}
\hline \multicolumn{2}{|c|}{$\begin{array}{c}\text { Đă̆c điếm của đối } \\
\text { tượng nghiên cứu }\end{array}$} & $\mathbf{n}$ & $\%$ \\
\hline \multirow{3}{*}{ Tuổi } & $\leq 2$ tháng & 25 & 23,15 \\
\cline { 2 - 4 } & $3-12$ tháng & 76 & 70,37 \\
\cline { 2 - 4 } & $>12$ tháng & 7 & 6,48 \\
\cline { 2 - 4 } & Trung bình & $5,8 \pm 3,85$ \\
\hline \multirow{2}{*}{ Giới } & Nam & 87 & 80,56 \\
\cline { 2 - 4 } & Nữ & 21 & 19,44 \\
\hline \multirow{2}{*}{ Địa chì } & Thành thị & 70 & 64,81 \\
\cline { 2 - 4 } & Nông thôn & 38 & 35,19 \\
\hline
\end{tabular}

Nhân xét: Tuối trung bình của trẻ VTPQ là 5,8 tháng. Nhóm trẻ từ 3 đến 12 tháng chiếm tỷ lệ hơn $70 \%$. Tỷ lệ trẻ nam/nữ là $4 / 1$. Tỷ lệ trẻ sống ở thành thị là $64,81 \%$.

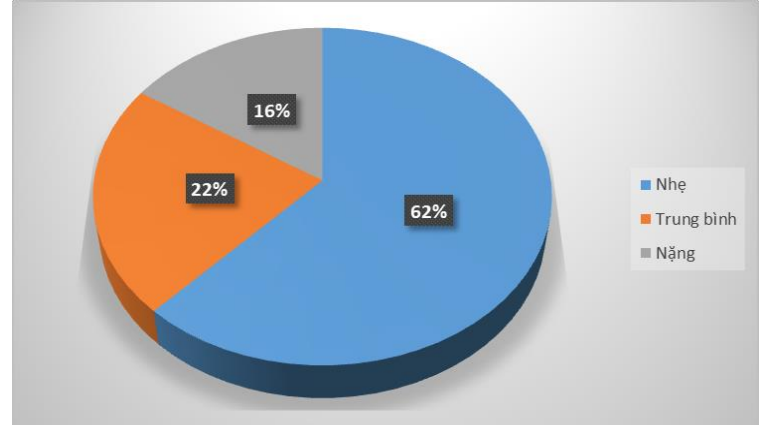

Biểu đồ 1. Phân bố mức độ nặng của bệnh

Nhận xét: Viêm tiểu phế quản mức độ nhẹ gặp với tỷ lệ cao nhất là $62 \%$, sau đó là mức độ trung bình là $22 \%$ và mức độ nặng là $16 \%$.

Bảng 2: Nồng độ 25-(OH)D huyết thanh ở trẻ viêm tiểu phế quản

\begin{tabular}{|c|c|c|c|c|c|}
\hline \multicolumn{2}{|c|}{ Nồng độ 25-(OH)D (nmol/l) } & \multicolumn{2}{|c|}{$\mathbf{n}$} & \multicolumn{2}{|c|}{ Tỷ lệ (\%) } \\
\hline \multicolumn{2}{|c|}{$\begin{array}{c}<30 \\
30-<50\end{array}$} & $\frac{3}{13}$ & 16 & $\begin{array}{l}2,78 \\
1204\end{array}$ & 14,82 \\
\hline \multirow{2}{*}{$50-<250$} & $50-<75$ & 22 & \multirow{2}{*}{91} & 20,37 & \multirow{2}{*}{84,26} \\
\hline & $\geq 75-250$ & 69 & & 63,89 & \\
\hline \multicolumn{2}{|c|}{$\geq 250 \mathrm{nmol} / \mathrm{I}$} & \multicolumn{2}{|c|}{1} & \multicolumn{2}{|c|}{0,93} \\
\hline
\end{tabular}

Nhận xét: ớ trẻ VTPQ, tỷ lệ thiếu vitamin D là 14,82\%, trong đó tỷ lệ thiếu vitamin D nặng (nồng 
độ $25-(\mathrm{OH}) \mathrm{D}<30 \mathrm{nmol} / \mathrm{l}$ ) là $2,78 \%$, thiếu vitamin $\mathrm{D}$ nhẹ (nồng độ $25-(\mathrm{OH}) \mathrm{D}$ từ $30-<50 \mathrm{nmol} / \mathrm{l}$ ) là $12,04 \%$.

Bảng 3: Liên quan giứa nồng độ 25-(OH)D và mức độ nặng của VTPQ

\begin{tabular}{|c|c|c|c|c|c|}
\hline \multirow{2}{*}{ Nồng độ 25-(OH)D (nmol/I) } & \multicolumn{5}{|c|}{ Mức độ nặng viêm tiểu phế quản } \\
\cline { 2 - 6 } & & Nhẹ & Trung bình & Nặng & Tống \\
\hline \multirow{2}{*}{$\geq 75$} & $\mathrm{n}$ & 50 & 11 & 9 & 70 \\
\hline \multirow{2}{*}{$<75$} & $\mathrm{n}$ & 71,43 & 15,71 & 12,86 & 100 \\
\hline & $\%$ & 17 & 13 & 8 & 38 \\
\hline \multicolumn{2}{|c|}{$\mathrm{p}$} & 44,74 & 34,21 & 21,05 & 100 \\
\hline
\end{tabular}

Nhân xét: $21,05 \%$ trẻ có nồng đô $25-(\mathrm{OH}) \mathrm{D}$ dưới $75 \mathrm{nmol} / \mathrm{l}$ mắc VTPQ ở mức đô năng so với $12,86 \%$ ở nhóm có nồng độ $25-(\mathrm{OH}) \mathrm{D} \geq 75 \mathrm{nmol} / \mathrm{l}$. Ngược lại, $71,43 \%$ trẻ có nồng độ $25-(\mathrm{OH}) \mathrm{D} \geq 75$ nmol/I mắc VTPQ mức độ nhẹ so với 44,74\% ở nhóm có nồng độ $25-(\mathrm{OH}) \mathrm{D}$ dưới $75 \mathrm{nmol} / \mathrm{l}$, sự khác biệt về mức độ nặng của VTPQ liên quan đến nồng độ $25-(\mathrm{OH}) \mathrm{D}$ có ý nghĩa thống kê với $\mathrm{p}=0,022$ $(<0,05)$.

Bảng 4: Liên quan giữa nồng độ 25-(OH)D và mức độ nặng của VTPQ có nhiễm RSV

\begin{tabular}{|c|c|c|c|c|c|}
\hline \multirow{2}{*}{\multicolumn{2}{|c|}{ Nông độ 25-(OH)D (nmol/l) }} & \multicolumn{4}{|c|}{ Mức độ nặng viêm tiếu phế quản } \\
\hline & & Nhẹ & Trung bình & Nặng & Tống \\
\hline \multirow{2}{*}{$\geq 75$} & $\mathrm{n}$ & 23 & 2 & 5 & 30 \\
\hline & $\%$ & 76,67 & 6,67 & 16,67 & 100 \\
\hline \multirow{2}{*}{$<75$} & $\mathrm{n}$ & 6 & 5 & 7 & 18 \\
\hline & $\%$ & 33,33 & 27,78 & 38,89 & 100 \\
\hline \multicolumn{2}{|c|}{$p$} & \multicolumn{4}{|c|}{0,008} \\
\hline
\end{tabular}

Nhân xét: Có 48 trẻ VTPQ có nhiễm RSV. Trong đó, 38,89\% nhóm có có nồng đô 25-(OH)D dưới $75 \mathrm{nmol} / \mathrm{l}$ mắc VTPQ mức độ nặng so với $16,67 \%$ ở nhóm có nồng độ $25-(\mathrm{OH}) \mathrm{D} \geq 75 \mathrm{nmol} / \mathrm{l}$. Ngược lại, có 33,33\% nhóm có nồng độ $25-(\mathrm{OH}) \mathrm{D}<75 \mathrm{nmol}$ mắc VTPQ mức độ nhẹ so với 76,67\% ở nhóm có nồng độ $25-(\mathrm{OH}) \mathrm{D} \geq 75 \mathrm{nmol} / \mathrm{l}$, sự khác biệt có ý nghĩa thống kê với $\mathrm{p}=0,008(<0,05)$.

\section{BÀN LUÂ̂N}

Trong thời gian 1 năm, có 108 trẻ VTPQ đủ tiêu chuẩn được mời tham gia nghiên cứu với độ tuổi trung bình là 5,8 tháng tuổi, tỷ lệ nam/nữ là $4 / 1$, tỷ lệ trẻ sống ở thành thị là $64,81 \%$. Phần lớn trẻ mắc VTPQ mức độ nhẹ với $62 \%$, VTPQ mức độ trung bình và nặng lần lượt là $22 \%$ và $16 \%$. Kết quả nghiên cứu này tướng đồng với kết quả của nhiều nghiên cứu khác trên thế giới, như nghiên cứu của Mahyar và cộng sự, nhóm VTPQ thường gặp nhất là viêm tiểu phế quản mức độ nhẹ (6).

Tỷ lệ trẻ VTPQ thiếu Vitamin D là $14,82 \%$, trong đó tỷ lệ thiếu vitamin $D$ nặng là $2,78 \%$ và thiếu vitamin $\mathrm{D}$ nhẹ là $12,04 \%$. Tỷ lệ này tương đương tỷ lệ trong nghiên cứu của Avraham và cộng sự (tỷ lệ thiếu vitamin D khoảng 10\%) (7) và thấp hơn tỷ lệ thiếu vitamin $D$ trong nghiên cứu Golan và cộng sự (8), với tỷ lệ thiếu vitamin D trong nhóm trẻ VTPQ là $73 \%$. Sự khác biệt có thể được giải thích do sự khác biệt bởi đối tượng nghiên cứu và địa dư tiến hành nghiên cứu. Trong nghiên cứu của chúng tôi, có thể do đối tượng nghiên cứu phần lớn sinh sống ở thành thị, có trình độ văn hóa cao và có điều kiện bổ sung vitamin $D$ thường xuyên và đầy đủ hơn.
Trong nhóm trẻ VTPQ có nồng độ 25- $(\mathrm{OH}) \mathrm{D}$ từ $75 \mathrm{nmol} / \mathrm{l}$ trở lên, tỷ lệ trẻ VTPQ mức độ nhẹ hay gặp nhất với hơn $70 \%$. Ngược lại, trong nhóm trẻ có nồng độ $25-(\mathrm{OH}) \mathrm{D}$ dưới $75 \mathrm{nmol} / \mathrm{l}$, tỷ lệ trẻ VTPQ mức độ nhe là 44,74\%. 21,05\% trẻ có nồng độ $25-(\mathrm{OH}) \mathrm{D}$ dưới $75 \mathrm{nmol} / \mathrm{l}$ mắc VTPQ ở mức độ nặng so với $12,86 \%$ ở nhóm có nồng độ $25-(\mathrm{OH}) \mathrm{D} \geq 75 \mathrm{nmol} / \mathrm{l}$. Sự khác biệt này có ý nghĩa thống kê với $p=0,022$. Kết quả nghiên cứu của chúng tôi khác với kết quả nghiên cứu của Golan và cộng sự, tác giả không thấy có mối liên quan giữa nồng độ $25-(\mathrm{OH}) \mathrm{D}$ và mức độ nặng của viêm tiểu phế quản (8).

Virus hợp bào hô hấp (RSV) là nguyên nhân hàng đầu gây VTPQ ở trẻ em. Tỷ lệ nhiễm RSV trong VTPQ dao động từ 60-90\%. Trong số trẻ VTPQ có nhiễm RSV có nồng độ $25-(\mathrm{OH}) \mathrm{D}$ từ 75 nmol/l trở lên, tỷ lệ trẻ VTPQ mức độ nhe là $76,67 \%$ so với 33,33\% ở nhóm có nồng độ $25-$ $(\mathrm{OH}) \mathrm{D}$ dưới $75 \mathrm{nmol} / \mathrm{l}$. Ngược lại, 38,89\% nhóm có có nồng độ $25-(\mathrm{OH}) \mathrm{D}$ dưới $75 \mathrm{nmol} / \mathrm{l}$ mắc VTPQ mức độ nặng so với $16,67 \%$ ở nhóm có nồng độ $25-(\mathrm{OH}) \mathrm{D} \geq 75 \mathrm{nmol} / \mathrm{l}$. Sự khác biệt này có ý nghĩa thống kê với $p=0,008$. Kết quả nghiên cứu này khác với kết quả nghiên cứu của Beigelman và cộng sự, nghiên cứu không thấy có 
sự khác biệt về mức độ nặng của VTPQ có nhiễm RSV ở nhóm có nồng độ 25-(OH)D (7).

\section{KẾT LUÂ̂N}

Nồng độ $25-(\mathrm{OH}) \mathrm{D}$ có liên quan với mức độ nặng của viêm tiểu phế quản nói chung và viêm tiểu phế quản do RSV nói riêng.

\section{TÀI LIÊU THAM KHẢO}

1. Hall CB, Weinberg GA, Iwane MK, Blumkin AK, Edwards KM, Staat MA, et al. The Burden of Respiratory Syncytial Virus Infection in Young Children. N Engl J Med. 2009 Feb 5;360(6):588-98.

2. Mogire RM, Mutua A, Kimita W, Kamau A, Bejon $\mathbf{P}$, Pettifor JM, et al. Prevalence of vitamin D deficiency in Africa: a systematic review and meta-analysis. Lancet Glob Health. 2020 Jan;8(1):e134-42.

3. Laillou A, Wieringa F, Tran TN, Van PT, Le BM, Fortin S, et al. Hypovitaminosis D and mild hypocalcaemia are highly prevalent among young Vietnamese children and women and related to low dietary intake. PloS One. 2013;8(5):e63979.

4. Poh BK, Rojroongwasinkul N, Le Nguyen BK, Ruzita AT, Yamborisut U, Hong TN, et al. 25hydroxy-vitamin $D$ demography and the risk of vitamin $D$ insufficiency in the South East Asian nutrition surveys (SEANUTS). Asia Pac J Clin Nutr. 2016;25(3):538.

5. Barlow PG, Svoboda $P$, Mackellar A, Nash AA, York IA, Pohl J, et al. Antiviral Activity and Increased Host Defense against Influenza Infection Elicited by the Human Cathelicidin LL-37. PLOS ONE [Internet]. 2011 Oct 21 [cited 2020 Jan 21];6(10). Available from: https:// www.ncbi.nlm.nih.gov/pmc/articles/PMC3198734/

6. Mahyar A, Ayazi P, Abbasi M, Dalirani R, Taremiha $\mathbf{A}$, Javadi $\mathbf{A}$, et al. Evaluation of Serum 25-Hydroxy Vitamin D Levels in Children with Acute Bronchiolitis. Arch Pediatr Infect Dis. 2017 Apr 1;5.

7. Beigelman A, Castro M, Schweiger TL, Wilson

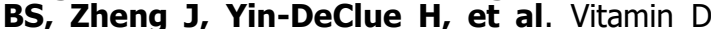
Levels Are Unrelated to the Severity of Respiratory Syncytial Virus Bronchiolitis Among Hospitalized Infants. J Pediatr Infect Dis Soc. 2015 Sep;4(3):182-8.

8. Golan-Tripto I, Loewenthal N, Tal A, Dizitzer Y, Baumfeld Y, Goldbart A. Vitamin D deficiency in children with acute bronchiolitis: a prospective cross-sectional case- control study. BMC Pediatr. 2021 Apr 30;21(1):211.

\section{ĐÁNH GIÁ MỨC Độ KHÓ KHĂN CỦA PHẪU THUÂT CẤY ĐIÊ̂N CỰC ỐC TAI VỚI Độ NGẢ SAU CỦA THÀNH SAU ỐNG TAI NGOÀI}

\section{TÓM TẮT}

Mục tiêu: Đối chiếu kết qưa đo độ ngả thành sau ống taii ngoài trên CLVT và phấu thuât, tữ đó đánh giá sự ảnh hưởng tới phẫu thuật. Phương pháp nghiên cứu: mô tả tiến cứu 25 bểnh nhân đước phẫu thuât cấy điện cực ốc tai. Kết quả nghiên cứu: Nhóm tuổi nhiêu nhất là 2-6 tuổi chiếm 48\%. ABR có 17 ca không có sóng V khi đo ở ngưỡng $90 \mathrm{~dB}$ chiếm $68 \%$, ASSR 23 bệnh nhân có trung bình ngưỡng nghe trên $90 \mathrm{~dB}$ chiếm tỷ lệ $92 \%$. Trên CLVT, độ lớn góc ngả thành sau ống tai ngoài trung bình là $144,76^{\circ}$ với góc đo nhỏ nhất là $126^{\circ}$, góc đo lớn nhất $165^{\circ}$. Nhóm góc $\geq 145^{\circ}$ trên CLVT có tương quan ống tai ngoài ngả sau trong phâuu thuật và khả năng nhìn thấy cửa số tròn với giá trị $p=0,003(<0,05)$. Kết luâan: Độ lớn góc thành sau ống tai ngoài trên CLVT $\geq 145^{\circ}$ thì ngả sau, càng lớn càng ngả sau và càng ảnh hưởng đến khả năng nhìn thấy cửa sổ tròn, kéo dài thời gian phấu thuật, tăng nguy cơ gây biến chứng.

\footnotetext{
${ }^{1}$ Bệnh viện Sản Nhi Nghê An

²Bênh viên Đai hoc Y Hà Nôi

Chịu trách nhiệm chính: Nguyễn Thị Huyền Ngân

Email: huyennganqp@gmail.com

Ngày nhận bài: 3.6.2021

Ngày phản biên khoa họ: 29.7.2021

Ngày duyệt bài: 5.8.2021
}

\section{Nguyễn Thị Huyền Ngân ${ }^{1}$, Cao Minh Thành ${ }^{2}$}

Từ khóa: phẫu thuật cẫy ốc tai, ống tai ngoài ngả sau, ngách mặt, cửa sồ tròn.

\section{SUMMARY}

\section{TO EVALUATE THE DIFFICULT OF SURGERY} COCHLEAR IMPLANTATION WITH POSTERIOR RECLINE OF THE POSTERIOR WALL OF THE EXTERNAL AUDITORY CANAL

Objective: Compare the results the angle of posterior wall the external auditory canal on CT and surgery, thereby evaluating the influence on surgery. Methods: describing the research on 25 patients having operated cochlear. Results: The most common group is $2-6$ years old acounting $48 \%$. ABR at $90 \mathrm{~dB}$ intensity, 17 patients without $\mathrm{V}$ ware, acounting for $68 \%$, ASSR had 23 patients with average threshold over 90dB (deafness), acounting for $92 \%$. On CT scan, the mean angle of inclination of the posterior wall the external auditory canal was $144,76^{\circ}$ with the smallest measuring angle being $126^{\circ}$, the measuring angle was large. at least $165^{\circ}$. Angle group $\geq 145^{\circ}$ on CT has the correlation between the external auditory canal reclining in surgery and the ability to display round window withp $=0.003 \quad(<0.05)$. Conclusion: The greater the angle of inclination behind the external auditory canal on CT 145 degrees, the more posteriorly it will affect the visibility of the round window and prolong the surgery time, increasing 